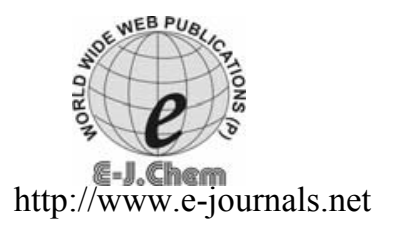

ISSN: 0973-4945; CODEN ECJHAO

E-Journal of Chemistry

2012, 9(1), 35-42

\title{
RP-HPLC Method Development and Validation for the Determination and Stability Indicative Studies of Montelukast in Bulk and its Pharmaceutical Formulations
}

\author{
A.PATNAIK ${ }^{\S *}$, S.S.PANDA ${ }^{\S}$, S.SAHOO ${ }^{\S}$ and V.J.PATRO \\ ${ }^{\S}$ Saraswati College of Pharmaceutical Sciences \\ Yethbarpally(v), Moinabad (M), R. R. Dist, Andhra Pradesh, India \\ Roland Institute of Pharmaceutical Sciences \\ Khodasinghi, Berhampur, Ganjam, Orissa, India \\ aravindapatnaik@gmail.com
}

Received 12 March 2011; Accepted 30 April 2011

\begin{abstract}
A simple, precise, accurate, economical and reproducible HPLC method for estimation of montelukast in tablet dosage form has been developed. Quantitative HPLC was performed with Shimadzu LC2010c HT with Winchrom Software with UV-Visible detector (SPD-IOA), PUMP (LC-IOAT) and (LC-IOATvp). Phenomenex $\mathrm{C}_{8}, 5 \mu \mathrm{m}, 25 \mathrm{~cm} \times 4.6 \mathrm{~mm}$ i.d. column was used in the study. The mobile phase of ACN: Acetate buffer $=6.5: 3.5 \mathrm{of} \mathrm{pH} 3$ were used in this study. The conditions optimized were: flow rate $(1 \mathrm{~mL} /$ minute), wavelength $(222 \mathrm{~nm})$ and run time was $20 \mathrm{~min}$. Retention time was found to be $3.08 \mathrm{~min}$. The linearity was found to be in the concentration range of $10-100 \mu \mathrm{g} / \mathrm{mL}$. The developed method was evaluated in the assay of commercially available tablet moni containing $10 \mathrm{mg}$ of montelukast. The amount of drug in tablet was found to be $10.34 \mathrm{mg} / \mathrm{tab}$ for the brand. Results of analysis were validated statistically and by recovery studies. The recovery studies $99.67 \%$ was indicative of the accuracy of proposed method. The precision was calculated as repeatability, inter and intraday variation (\%RSD) for the drug. By using the method, stability of the drug has been studied.
\end{abstract}

Keywords: Montelukast, RP-HPLC, Degradation studies, Pharmaceutical formulations

\section{Introduction}

It is necessary to find the content of each drug either in bulk or single or combined dosage forms for purity testing. It is also essential to know the concentration of the drug and it's metabolites in biological fluids after taking the dosage form for treatment. 
The scope of developing and validating an analytical method is to ensure a suitable method for a particular analyte more specific, accurate and precise ${ }^{1}$. The main objective for that is to improve the conditions and parameters, which should be followed in the development and validation.

Montelukast sodium (MTKT), 1-[(\{(R)-m-[(E)-2-(7-chloro-2-quinolyl) vinyl]- $\alpha$-[o(1-hydroxylmethylethyl)phenethyl]benzyl $\}$ thio)methyl] cyclopropaneacetate sodium is a leukotriene receptor antagonist, used in the treatment of asthma ${ }^{2,3}$. It is not official in IP, BP and USP. Various analytical methods, such as liquid chromatography with fluorescence detection $^{4-6}$ stereoselective HPLC for MTKT and its $S$-enantiomer ${ }^{7}$, simultaneous HPLC and derivative spectroscopic method with loratadine ${ }^{8}$, stability indicating HPLC $\operatorname{method}^{9}$ for Montelukast sodium in tablets and human plasma have been reported.

The present study illustrates development and validation of a simple, accurate and precise procedure for determination of montelukast sodium by RP-HPLC in bulk and in tablet dosage form.

\section{Experimental}

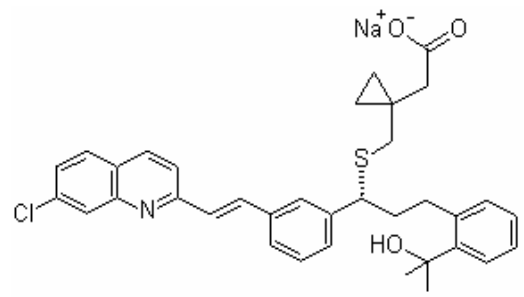

Figure 1. Montelukast sodium

The chromatographic separation was performed on Schimadzu LC2010c HT (Autosampler) with Winchrom Software with Isocratic--Gradient with UV-Visible Detector (SPD-IOA), PUMP (LC-IOAT). Phenomenex $\left(\mathrm{C}_{8}\right) \mathrm{RP}$ Column, $250 \mathrm{~mm} \times 4.6 \mathrm{~mm}$ has been used as a stationary phase. pH Analyzer (ELICO), Electronic Balance (AFCOSET), Ultra Sonicator (ENERTECH) has been used in the work. Montelukast sodium working standard was obtained from Wexford Laboratories Pvt. Ltd. in Peenya $2^{\text {nd }}$ Stage, Bangalore. Moni Tablets (Montelukast sodium tablets, $10 \mathrm{mg}$ ) was purchased from a local pharmacy store. Acetonitrile, acetic acid \& water of HPLC grade were taken from standard reagents, Hyderabad.

\section{Method development}

\section{Optimised chromatographic conditions}

The mobile phase of ACN: Acetate buffer $(\mathrm{pH} 3)=6.5: 3.5$ were used in this study. The conditions optimized were: flow rate $(1 \mathrm{~mL} /$ minute), wavelength $(222 \mathrm{~nm})$ and run time was $20 \mathrm{~min}$, injection volume $20 \mu \mathrm{L}$. Retention time was found to be $3.08 \mathrm{~min}$. Phenomenex $\mathrm{C}_{8}$, $5 \mu \mathrm{m}, 25 \mathrm{~cm} \times 4.6 \mathrm{~mm}$ i.d. column was used in the study.

\section{Preparation of standard drug solutions}

Standard stock solution of a concentration of $100 \mu \mathrm{g} / \mathrm{mL}$ of montelukast was prepared by using mobile phase.

\section{Preparation of mobile phase}

The mobile phase used in this analysis consists of a mixture of glacial acetic acid and acetonitrile in a ratio of 35:65 $\mathrm{pH}$ of the solution adjusted to 3.0 . 


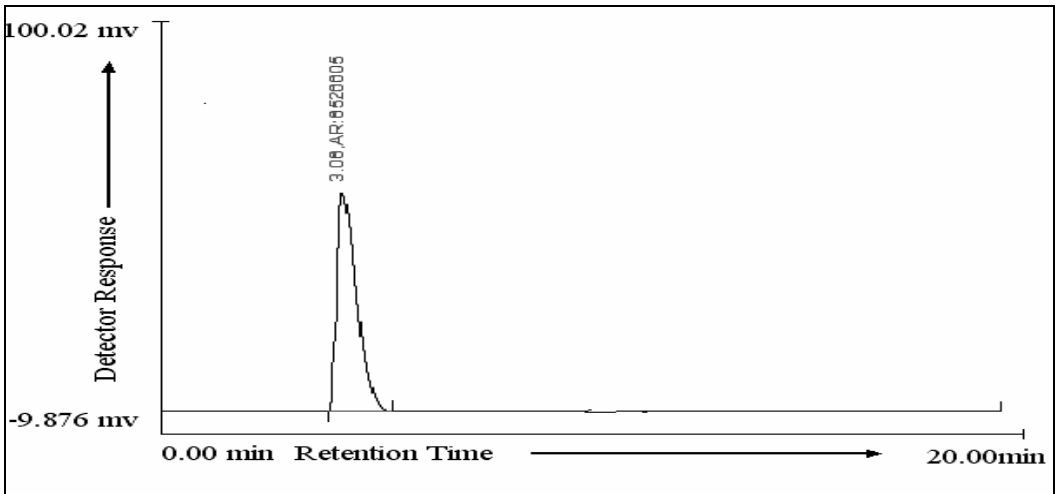

Figure 2. HPLC spectrum of montelukast (100 ppm) in optimized conditions (RT $3.08 \mathrm{~min}$ )

\section{Preparation of calibration curve}

Calibration curve was prepared by taking appropriate aliquots of standard montelukast stock solution in different $10 \mathrm{~mL}$ volumetric flask and diluted up to the mark with mobile phase to obtain the final concentrations of $10-100 \mu \mathrm{g} / \mathrm{mL}$ of montelukast. The calibration curve has been shown below. Standard solutions $(n=6)$ were injected, the sample volume was $20 \mu \mathrm{L}$ with a flow rate of $1.0 \mathrm{~mL} / \mathrm{min}$.

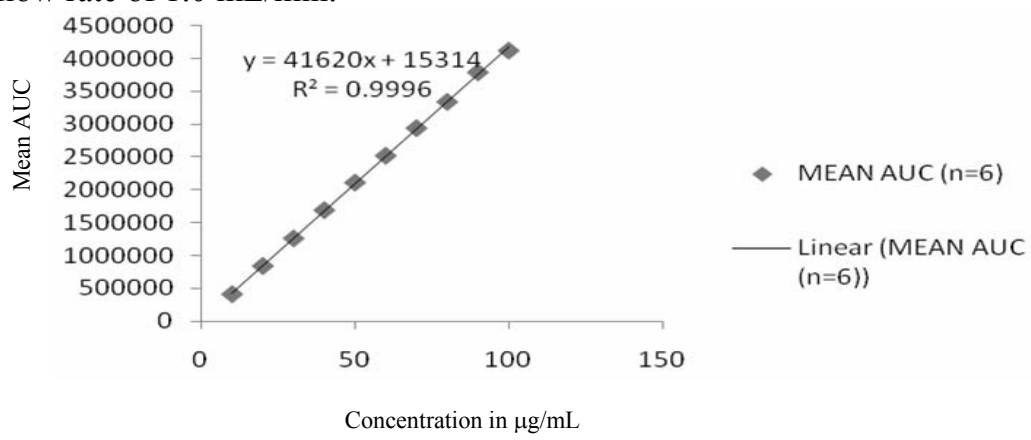

Figure 3. Calibration curve of .montelukast

Table 1. Results for construct the calibration curve

\begin{tabular}{cc}
\hline Conc, $\mu \mathrm{g} / \mathrm{mL}$ & Mean AUC $(\mathrm{n}=6)$ \\
\hline 10 & 410341 \\
20 & 841309 \\
30 & 1261332 \\
40 & 1691734 \\
50 & 2112310 \\
60 & 2521649 \\
70 & 2943094 \\
80 & 3343921 \\
90 & 3793994 \\
100 & 4124588 \\
\hline
\end{tabular}




\section{Forced degradation studies}

\section{Acid hydrolysis $(0.1 \mathrm{M} \mathrm{Hcl})$}

An accurately weighed $10 \mathrm{mg}$ of pure drug was transferred to a clean and dried $10 \mathrm{~mL}$ volumetric flask. To which $0.1 \mathrm{M}$ Hydrochloric acid was added and made up to the mark and kept for $24 \mathrm{~h}$. From that $1 \mathrm{~mL}$ was taken in to a $10 \mathrm{~mL}$ volumetric flask and make up to the mark with mobile phase, then injected into the HPLC system against a blank of $\mathrm{HCl}$ and mobile phase (after all optimized conditions).

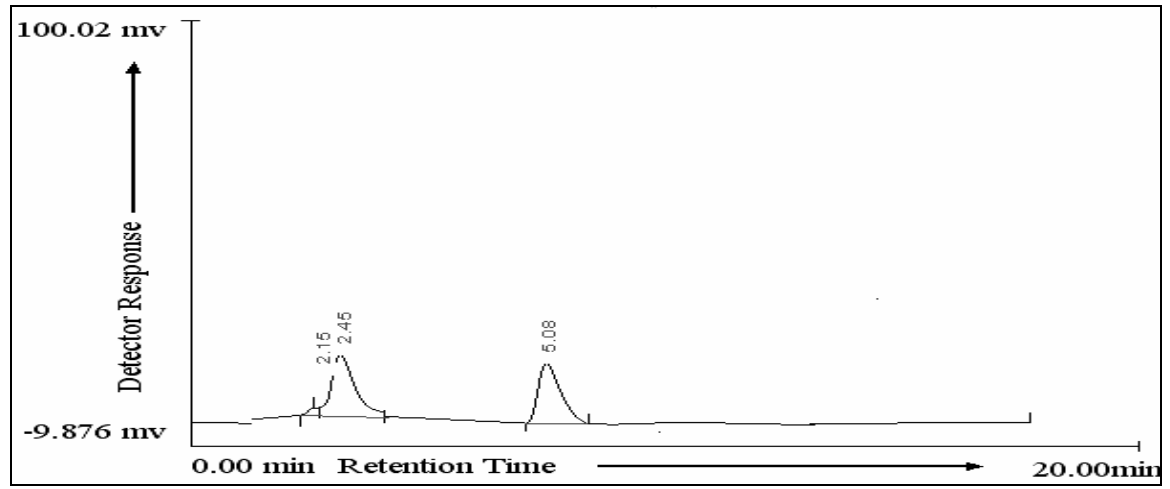

Figure 4. Chromatogram showing degradation in $0.1 \mathrm{M} \mathrm{HCl}$

\section{Basic hydrolysis (0.1 $\mathrm{M} \mathrm{NaOH)}$}

An accurately weighed $10 \mathrm{mg}$. of pure drug was transferred to a clean and dried $10 \mathrm{~mL}$ volumetric flask. To which $0.1 \mathrm{M}$ sodium hydroxide was added and made up to the mark and kept for $24 \mathrm{~h}$. From that $1 \mathrm{~mL}$ was taken in to a $10 \mathrm{~mL}$ volumetric flask and made up to the mark with mobile phase, then injected into the HPLC system against a blank of $\mathrm{NaOH}$ and mobile phase (after all optimized conditions).

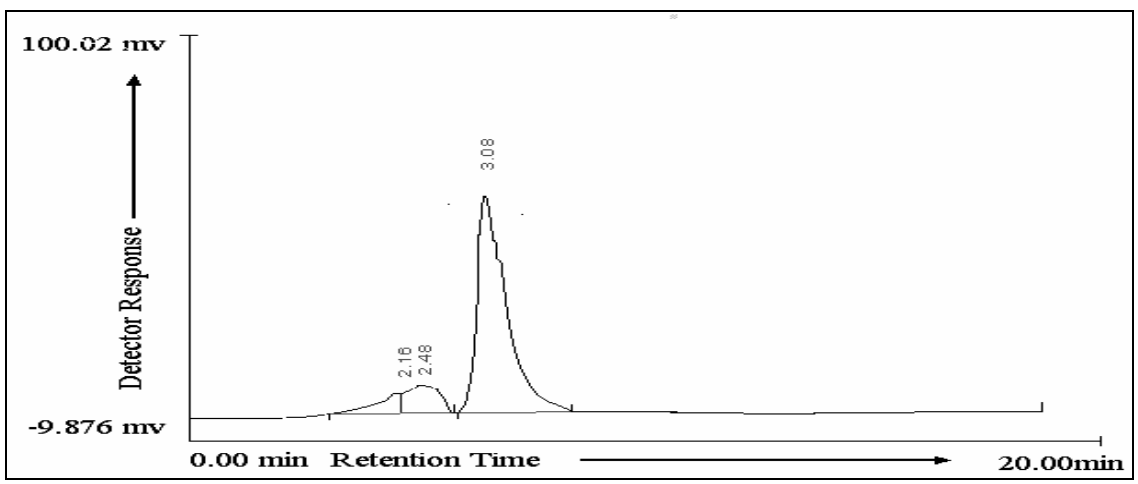

Figure 5. Chromatogram showing degradation in $0.1 \mathrm{M} \mathrm{NaOH}$

Oxidation with (3\%) $\mathrm{H}_{2} \mathrm{O}_{2}$

An accurately weighed $10 \mathrm{mg}$. of pure drug was transferred to a clean and dried $10 \mathrm{~mL}$ volumetric flask. To which $3 \%$ hydrogen peroxide was added, made up to the mark and kept for $24 \mathrm{~h}$. From that $1 \mathrm{~mL}$ was taken in to a $10 \mathrm{~mL}$ volumetric flask and made up to the mark with mobile phase, then injected into the HPLC system against a blank of $\mathrm{H}_{2} \mathrm{O}_{2}$ and mobile phase (after all optimized conditions). 


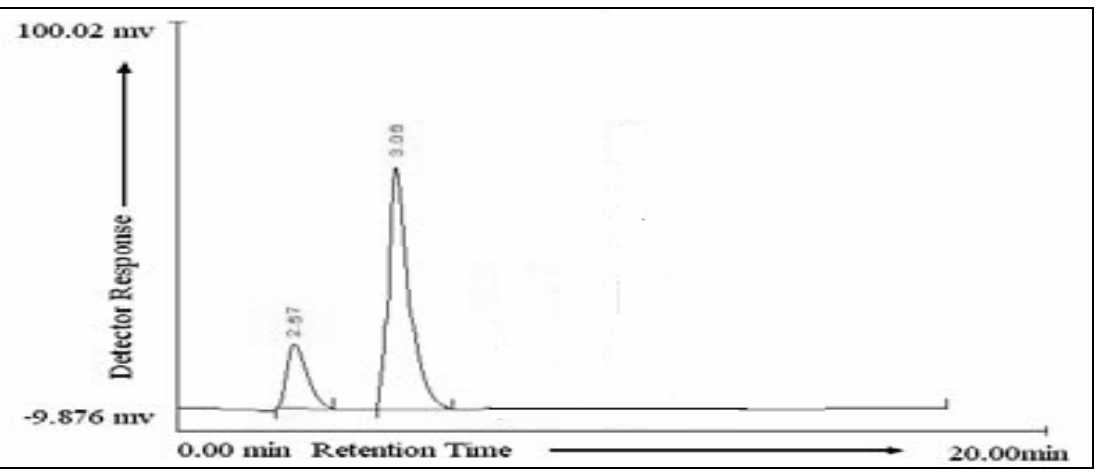

Figure 6. Chromatogram showing degradation in $3 \% \mathrm{H}_{2} \mathrm{O}_{2}$

\section{Thermal degradation}

An accurately weighed $10 \mathrm{mg}$ of pure drug was transferred to a clean and dry $100 \mathrm{~mL}$ volumetric flask, made up to the mark with methanol and was maintained at $50{ }^{\circ} \mathrm{C}$ for $24 \mathrm{~h}$ then injected into the HPLC system against a blank of mobile phase (after all optimized conditions).

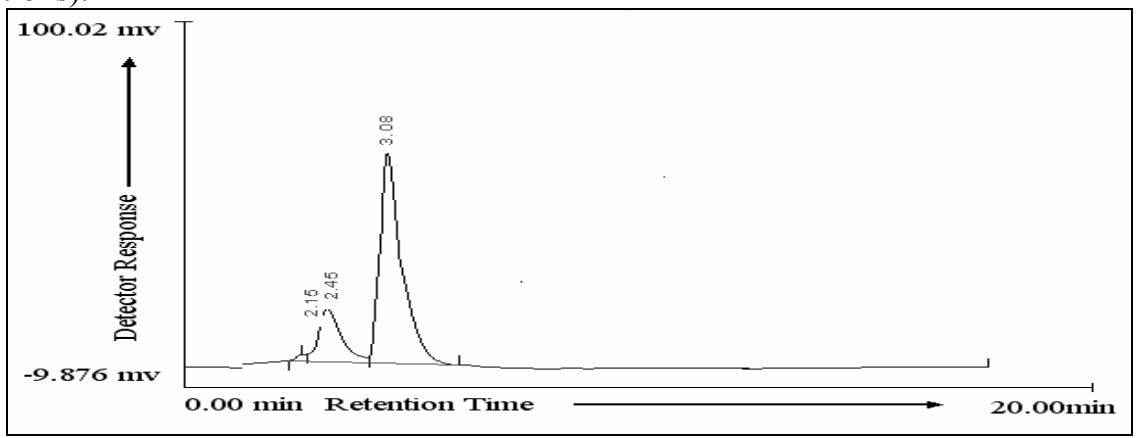

Figure 7. Chromatogram showing thermal degradation

\section{Phtolytic degradation}

Approximately $10 \mathrm{mg}$. of pure drug was taken in a clean and dry Petridis. It was kept in a UV cabinet at $254 \mathrm{~nm}$ wavelength for $24 \mathrm{~h}$ without interruption. Accurately weighed $1 \mathrm{mg}$. of the UV exposed drug was transferred to a clean and dried $10 \mathrm{~mL}$ volumetric flask. First the UV exposed drug was dissolved in methanol and make up to the mark than injected into the HPLC system against a blank of mobile phase (after all optimized conditions).

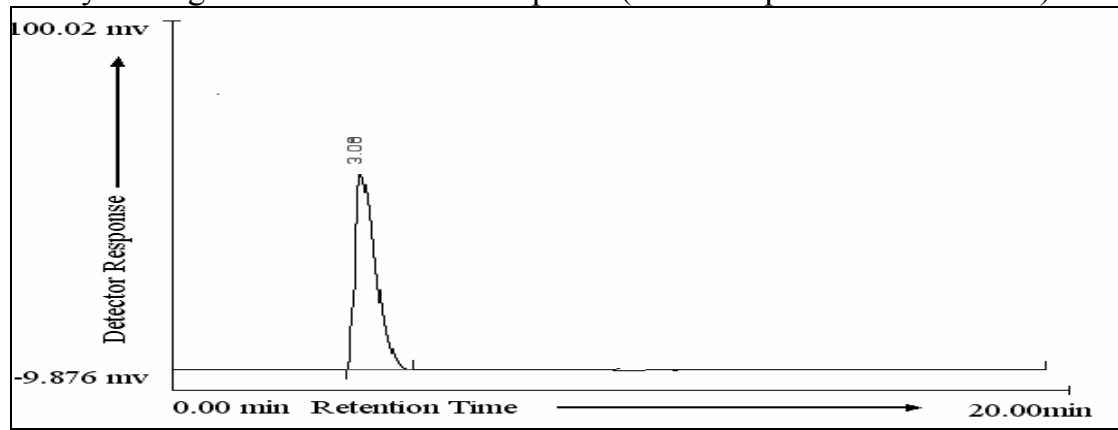

Figure 8. Chromatogram showing photolytic degradation 


\section{Results and Discussion}

\section{Results of degradation studies}

The results of the stress studies indicated the specificity of the method that has been developed. The result of forced degradation studies are given in the following table.

Table 2. Results of force degradation studies of montelukast

\begin{tabular}{ccccc}
\hline Stress condition & Time & $\begin{array}{c}\text { Assay of active } \\
\text { substance }\end{array}$ & $\begin{array}{c}\text { Assay of degraded } \\
\text { products }\end{array}$ & $\begin{array}{c}\text { Mass } \\
\text { balance, \% }\end{array}$ \\
\hline $\begin{array}{c}\text { Acid Hydrolysis } \\
(0.1 \mathrm{M} \mathrm{HCl})\end{array}$ & $24 \mathrm{H}$ & - & 97.56 & 97.56 \\
$\begin{array}{c}\text { Basic Hydrolysis } \\
(0 . \mathrm{I} \mathrm{M} \mathrm{NaOH})\end{array}$ & $24 \mathrm{H}$ & 80.27 & 19.06 & 99.33 \\
$\begin{array}{c}\text { Oxidation(3\% H2O2) } \\
\text { Thermal Degradation } \\
(500 \mathrm{C})\end{array}$ & $24 \mathrm{H}$ & 78.73 & 19.86 & 98.61 \\
UV $(254 \mathrm{~nm})$ & $24 \mathrm{H}$ & 89.47 & 10.11 & 99.58 \\
\hline
\end{tabular}

\section{Method validation}

Accuracy recovery study

To determine the accuracy of the proposed method, recovery studies were carried out by adding different amounts $(80 \%, 100 \%$ and $120 \%)$ of pure drug of montelukast were taken and added to the pre-analyzed formulation of concentration $10 \mu \mathrm{g} / \mathrm{mL}$. From that percentage recovery values were calculated. (Procedure repeated for six times).

\section{Precision}

\section{Repeatability}

The precision of each method was ascertained separately from the peak areas \& retention times obtained by actual determination of five replicates of a fixed amount of drug. montelukast (API) The percent relative standard deviation were calculated for montelukast.

\section{Intra-assay and inter-assay}

The intra and inter day variation of the method was carried out and the high values of mean assay and low values of standard deviation and \% RSD $(\% \operatorname{RSD}<2 \%)$ within a day and day to day variations for montelukast revealed that the proposed method is precise. (Procedure repeated for six times).

\section{Linearity and range}

The calibration curve showed good linearity in the range of $10-100 \mu \mathrm{g} / \mathrm{mL}$, for montelukast (API) with correlation coefficient $\left(\mathrm{r}^{2}\right)$ of 0.999 (Figure 3). A typical calibration curve has the regression equation of $\mathrm{y}=41620 \mathrm{x}+15314$ for montelukast.

\section{Method robustness}

Influence of small changes in chromatographic conditions such as change in flow rate $( \pm 0.1 \mathrm{~mL} / \mathrm{min})$, temperature $\left( \pm 2{ }^{0} \mathrm{C}\right)$, wavelength of detection $( \pm 2 \mathrm{~nm})$ and methanol content in mobile phase $( \pm 2 \%)$ studied to determine the robustness of the method are also in favour of $(\% \mathrm{RSD}<2 \%)$ the developed RP-HPLC method for the analysis of montelukast (API). 


\section{$L O D$ and $L O Q$}

The minimum concentration level at which the analyte can be reliable detected (LOD) and quantified (LOQ) were found to be 0.03 and $0.09 \mu \mathrm{g} / \mathrm{mL}$ respectively.

\section{Specificity and stability in analytical solution}

The results of specificity indicated that the peak was pure in presence of degraded sample. It is important to mention here that the montelukast (API) was stable in solution form up to $24 \mathrm{~h}$ at $25^{\circ} \mathrm{C}$.

The results of linearity, precision, inter and intraday assays, method robustness, LOD, LOQ, specificity and stability in analytical solution established the validation of the developed RP-HPLC method for analysis of montelukast.

Table 3. Summary of validation parameters By RP-HPLC method

\begin{tabular}{lcc}
\hline Validation parameters & & Montelukast \\
\hline Specificity & & $\%$ interference $<0.5 \%$ \\
Range, $\mu \mathrm{g} / \mathrm{mL}$ & Linear range & $10-100 \mu \mathrm{g} / \mathrm{mL}$ \\
& Working range & $0.03-100 \mu \mathrm{g} / \mathrm{mL}$ \\
& Target range & $44,55,60.5 \mu \mathrm{g} / \mathrm{mL}$ \\
& Target concentration & $55 \mu \mathrm{g} / \mathrm{mL}$ \\
Accuracy (\% Recovery) & $80,100,120$ & $99.67,99.19,99.49$ \\
Precision (\% RSD) & Repeatability & 0.865 \\
& Intra day, $10,30,100 \mu \mathrm{g} / \mathrm{mL}$ & $1.05,0.55,0.18$ \\
& Inter day, $10,30,100 \mu \mathrm{g} / \mathrm{mL}$ & $0.24,0.41,0.18$ \\
LOD, $\mu \mathrm{g} / \mathrm{mL}$ & & 0.03 \\
LOQ, $\mu \mathrm{g} / \mathrm{mL}$ & & 0.09 \\
\hline
\end{tabular}

Assay of montelukast in dosage form

Assay was performed as described in previous chapter. Results obtained are tabulated below:

Table 4. Assay of montelukast tablet

\begin{tabular}{cccc}
\hline $\begin{array}{c}\text { Brand name } \\
\text { of tablets }\end{array}$ & $\begin{array}{c}\text { Labeled amount of } \\
\text { Drug, mg }\end{array}$ & $\begin{array}{c}\text { Mean }( \pm \mathrm{SD}) \text { amount }(\mathrm{mg}) \text { found } \\
\text { by the proposed method }(\mathrm{n}=6)\end{array}$ & $\begin{array}{c}\text { Mean Assay } \\
( \pm \mathrm{SD})(\mathrm{n}=6)\end{array}$ \\
\hline Moni & 10 & $10.34( \pm 0.06)$ & $100.88( \pm 0.48)$ \\
\hline
\end{tabular}

The assay of Moni tablet containing montelukast was found to be $100.88 \%$ as per the method.

\section{Conclusion}

The proposed method is simple, sensitive and reproducible and hence can be used in routine for determination of montelukast in bulk as well as in pharmaceutical preparations. Statistical analysis of the results has been carried out revealing high accuracy and good precision.

\section{Acknowledgment}

The authors are thankful to the Director of Startech Pvt Ltd, Hyderabad for providing the necessary facilities to carry out this work. 


\section{References}

1. Rockville M D, United States Pharmacopoeia; United States Pharmacopoeial Convention Inc, $25^{\text {th }}$ Edn., 2002, 1, 2150.

2. Budavari S, Editor. The Merck Index. $12^{\text {th }}$ Ed., Whitehouse Station, N J: Merck \& Co Inc.; 1996, 1070.

3. Morrow J D and Roberts L J, In: Goodman and Gilman's, The Pharmacological Basis of Therapeutics. $10^{\text {th }}$ Ed., Hardman JG, Limbird L E and Gilman A G, Editors. New York: McGraw-Hill; 2001, 669.

4. Al-Rawithi S, Al-Gazlan S, Al-Ahmadi W, Alshowaier I, Yusuf A and Raines D, $J$ Chromatogr B Biomed Sci Appl., 2001;754:527-31.

5. Ochiai H, Uchiyama N, Takano T, Hara K and Kamei T, J Chromatogr B Biomed Appl., 1998, 713, 409-14.

6. Chauhan B, Shubha Rani, Nivsarkar M and Padh H, Indian J Pharm Sci., 2006, 68, 517-20.

7. Radhakrishna T, Narasaraju A, Ramakrishna M and Satyanarayana A, J Pharm Biomed Anal., 2003, 31, 359-68.

8. Alsarra I, Saudi Pharm J., 2004, 12, 136-43.

9. Sweetman S C, Editor. Martindale: The Complete Drug Reference. $33^{\text {rd }}$ Ed., London: Pharmaceutical Press, 2002, p 761. 


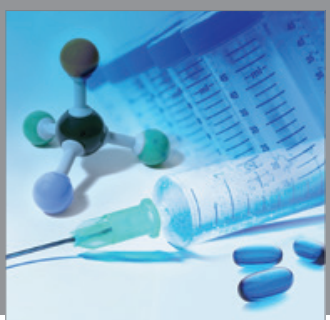

International Journal of

Medicinal Chemistry

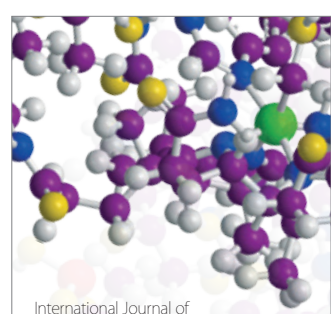

Carbohydrate Chemistry

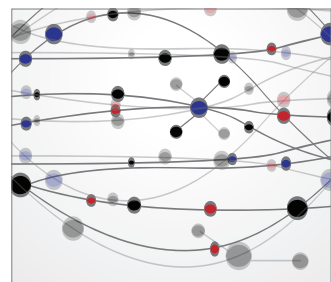

The Scientific World Journal
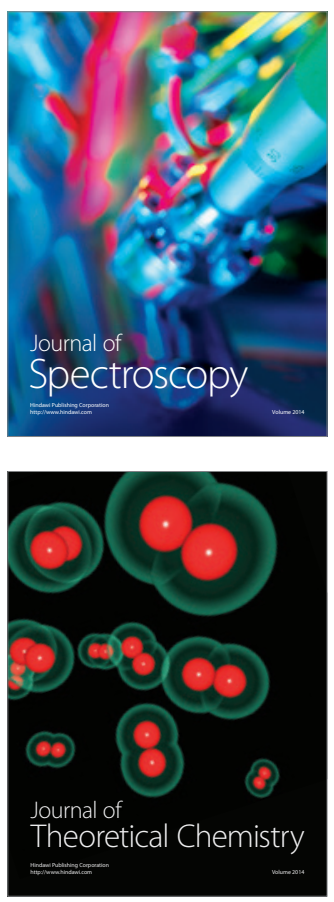
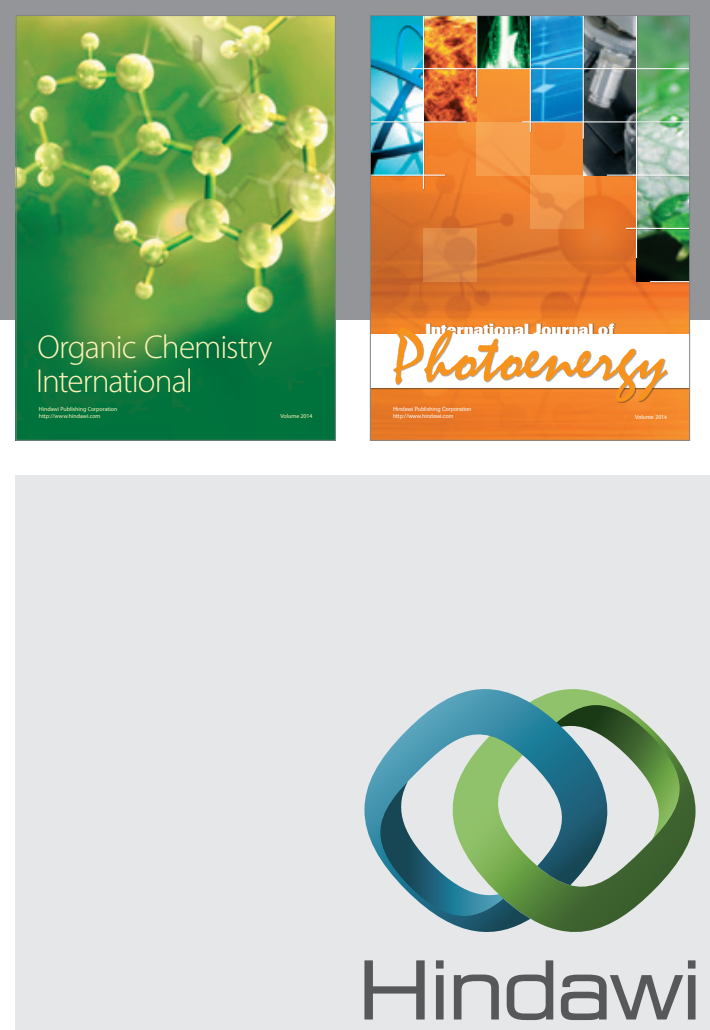

Submit your manuscripts at

http://www.hindawi.com
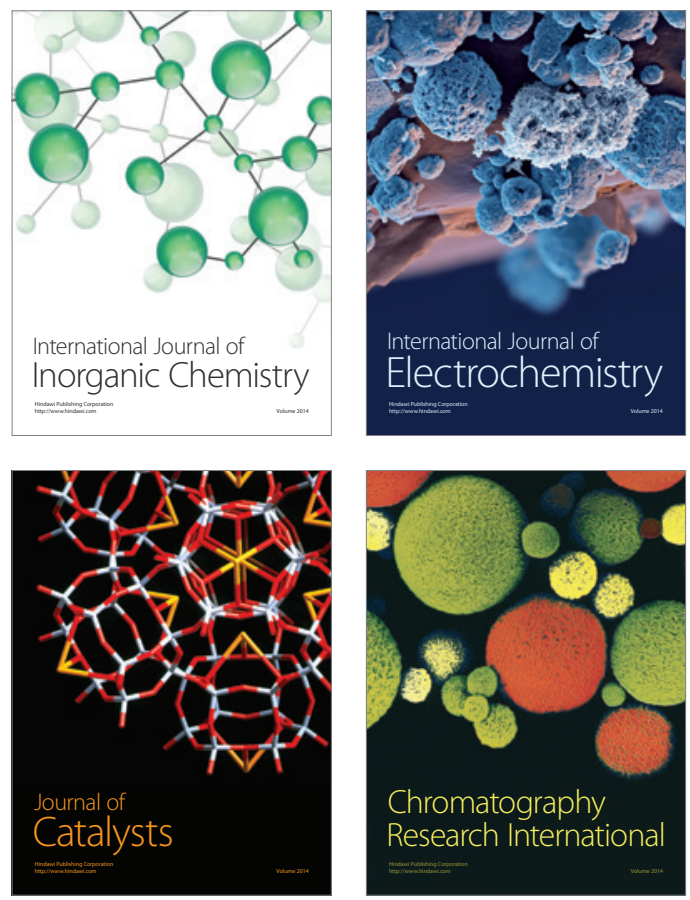
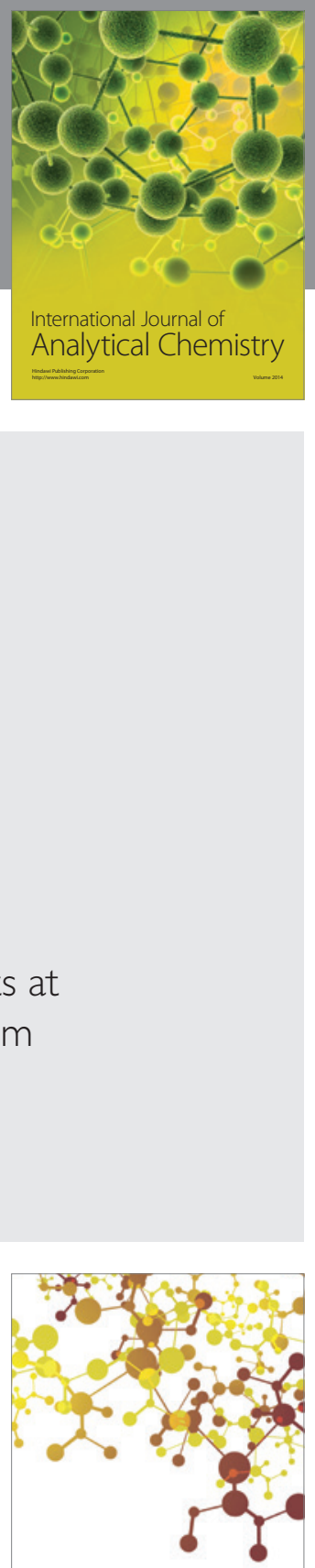

Journal of

Applied Chemistry
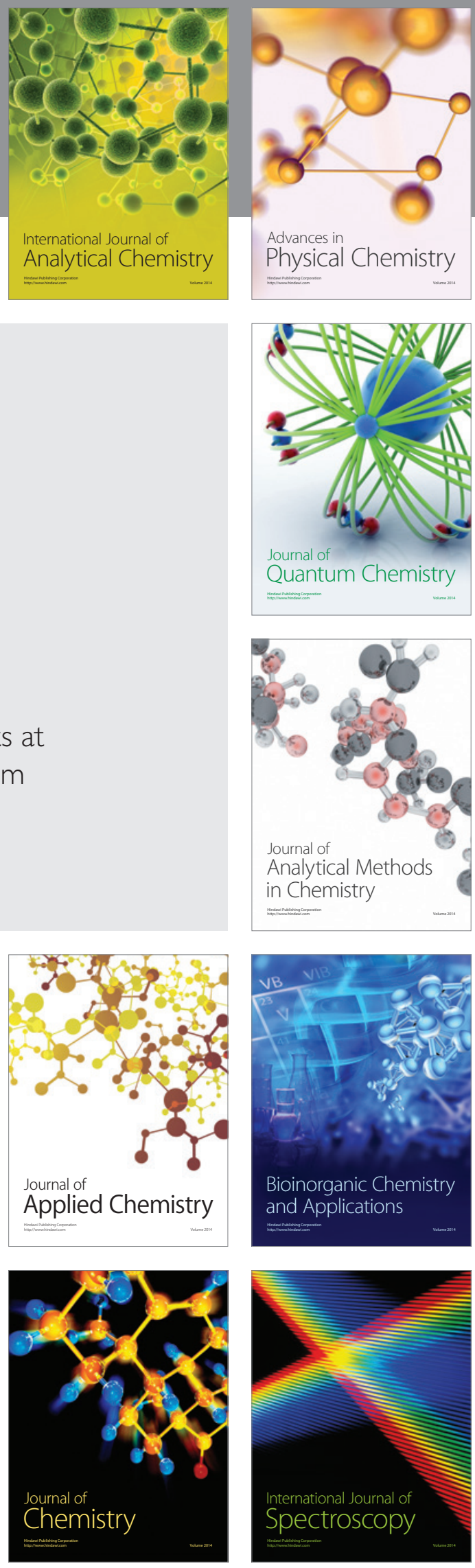